\title{
Can Mobile Learning Be An Opportunity for Undergraduate Teacher Education?
}

\author{
Mehmet Eroğlu \\ Firat University, Faculty of Education, Elazig/ Turkey \\ Vildan Donmuş Kaya \\ Firat University, Faculty of Education, Elazig/ Turkey \\ Ramazan Özbek \\ İnonu University, Faculty of Education, Malatya/ Turkey
}

\begin{abstract}
The purpose of research is to determine the usability of mobile learning in undergraduate teacher education. In the first part of the study, researches on mobile learning opportunities in undergraduate teacher education and teacher education are examined. In the second part of the study, infrastructure and readiness for mobile learning of prospective teachers are examined in terms of some variables. The research is designed in survey model. The sample of the research is composed of 454 prospective teachers who study in the 1 st and 4 th grade of Firat University Faculty of Education. Participant demographic form and the readiness scale for mobile learning developed by Lin, Lin, Yeh and Wang (2016) adapted to Turkish by Gökçeaslan, Solmaz and Kukul (2016) is used as data collection tool. Statistical techniques such as mean, frequency, percentage, $t$ test, one way anova are used in the analysis of the data. The research findings revealed by examining the relevant researches show that mobile learning offers important opportunities for undergraduate teacher education. Prospective teachers have mobile tools necessary for mobile learning and have opportunities access to internet. It is determined that prospective teachers frequently use mobile tools and use mobile tools partially for educational purposes. It is determined that the level of prospective teachers' readiness for mobile learning has partially high $(\bar{X}=3.60)$ and the level of prospective teachers' readiness for mobile learning is not differ according to gender, educational level and department variables. But prospective teachers' readiness for mobile learning differs according to the daily average internet usage time. The results of the research show that mobile learning is an approach that should be taken into account for undergraduate teacher education.
\end{abstract}

Keywords: Mobile learning, readiness for mobile learning, undergraduate teacher education.

\section{Introduction}

Today, there are rapid developments in information technologies. Today's developments in information technology affect the social lives, professional lives and habits of individuals(Wang \& Li, 2012). One of the most important factors that brought about this effect is mobile devices. Because mobile devices are often used at all ages, ubiquitous and offer significant opportunities for information access and learning(Abusson, Schuck \& Burden, 2009; Hussin et al., 2012; Newhouse, Williams, \& Pearson, 2006). These devices make our daily life a big deal easier(Işık, Özkaraca \& Güler, 2011, Yılmaz, 2011). Also the usage of mobile devices for mobile learning is becoming increasingly popular (Jacob and Issac, 2008). So, one of the concepts that have emerged in recent years in this context is mobile learning.

\section{What is mobile learning?}

Increase of portable computing/communication devices such as laptops, PDA(Personal Digital Assistant)s, smart phones, Ipads connected to wireless networks enable mobility and facilitate mobile learning (Jacob \& Issac, 2008). For this reason, the concept of mobile learning attracts researchers and practitioners recently. There are several definitions of mobile learning in literature. According to Quinn (2000), one of early definitions of mobile learning, "mobile learning is learning through mobile computational devices". Similarly according to Traxler (2005) mobie learning is "any educational provision 
where the sole or dominant technologies are handhold or palmtop devices". Early definitions of mobile learning was simply use of palm as a learning devices and they are centered on technology (Crompton, 2013). But there have been differences in definitions over time. O'Malley et al. (2003) defined mobile learning " any sort of learning that happens when the learner is not at a fixed predetermined location, or learning that happens when the learner takes advantages of learning opportunities offered by mobile technologies. Later definitions of mobile learning contains elements such as contexts, pedagogy, etc. (Crompton, 2013). According to the Walker (2006), mobile learning is not learning just using mobile devices, is learning between contexts. According to Crompton (2013), who studies this transformation in the concept of mobile learning, mobile learning is "learning across multiple context through social and content interactions, using personal devices. Mobile learning definitions are changing and different dimensions are emphasized over time (Baran, 2014).

\section{What are the advantages and disadvantages of mobile learning?}

Researches have revealed that mobile learning has many advantages. The most important advantage of mobile learning is that it allows us to learn anywhere and at any time(Attewell, 2005; Cheong \& Park, 2005; Geddes, 2004; Traxler, 2007). Mobile learning, is not just delivering contents via devices, play a facilitator role in for learning occurs different time and context (Pachler, Cook, Bachmair \& Kress; 2010). There are many research towards how mobile learning applications effect academic achievement and attitude (Al-Fahad, 2009; Chen, 2013; Cheon et al., 2012; Ciampa, 2014; Jaradat, 2014; Kutluk \& Gulmez, 2014; Martin \& Ertzberger, 2013; Sur, 2011), engagement and interest (Hwang \& Hsun, 2011; Wang et al., 2009; Ozan, 2013). Also there have been studies that demonstrated that mobile learning itself can be an effective learning approach or even better than traditional face-to-face lecturing approaches (Shih et al., 2010). Advantages that opportunity to learn without limit of time and place, increase the academic achievement, interest/engagement and motivation to make it possible to self directed learning increases the importance of mobile learning. Therefore mobile learning can be considered as an approach that should be taken into account in all levels of education today.

Mobile learning has some limitations as well as many advantages. The most comprehensive and systematic classification of the disadvantages of mobile learning in terms of learners was made by Shudong and Higgins (2005), (Çelik, 2013). The disadvantages of mobile learning are classified as technical, psychological and pedagogical. Mobile devices have some technical limitations in terms of mobile learning such as online connection status, costs, storage capacities, band width and specific security issues, lack of standardization and compatibility etc.(Shudong \& Higgins, 2005; Franklin, 2011; Behera, 2013). Psychological limitations are also important for mobile learning. The effectiveness of mobile learning can vary depending on the characteristics of the person (Sha et al., 2012). As well as some pedagogical limitations of mobile learning. Some technical limitations such as online connection status, lack of standardization, feedback problems etc. can cause pedagogical limitations (Shudong \& Higgins, 2005). Technical, psychological and pedagogical lımitations for mobile leraning may be connected each other. According to Chu (2014) mobile learning ineffectiveness could be caused by the heavy cognitive load as a result of an improper learning design. So the design of the mobile learner is important. If properly facilitated, mobile learning can be of great benefit to learners by providing instructional materials and interaction through their mobile devices wherever and whenever they are on the move (Jacob and Issac, 2008). So, only well-designed mobile learning can offer qualified learning opportunities.

\section{Mobile learning in Teacher Education}

The rapid developments in science and technology in the 21 st century have led to the redefinition of some educational concepts and the emergence of some new concepts. The concepts we need to focus on in this research context are the teaching profession and mobile learning. In this new definition, teaching is defined as a profession that requires lifelong learning(European Commission, 2005). Lifelong learning emphasizes that learning is continuous without depending on time and location(Güleç, Çelik \& Demirhan, 2012). When situation evaluated in this context, mobile learning, which offers learning opportunities independent of time and space, offers valuable opportunities for the training of teachers and prospective teachers. Prospective teachers should develop their lifelong learning process starting from the in service training. Because Today, teaching profession is more difficult and complicated than in the past. Teachers are expected to update and develop their skills so that they can meet the high academic standards required for them today and this is possible with professional development (Craft, 2001). Professional development is also a concept associated with lifelong learning (Scales, 2011). It is expected that undergraduate teacher education should start the professional development process of prospective teachers. For this reason mobile learning can offer important opportunities for the professional development of prospective teachers as well as other opportunities(Abusson, Shuck \& Burden, 2009; Christensen \& Knezek, 2017). According to Öz (2014), prospective teachers have mobile devices for mobile learning and want to use 
them in lessons. While the majority of the existing research has focused primarily on the value of mobile learning for students, researchers have recently started exploring its potentials within teacher development (Abusson, Schuck \& Burden, 2009; Baran, 2014). Altough mobile learning has an important potential for teacher education it is under-theorized in teacher education (Kearney \& Maher, 2013). Therefore, more research on the use of mobile learning in teacher education (Baran, 2014).

It is aimed to investigate whether mobile learning is an opportunity for teacher education in current research. The studies on mobile learning for this purpose shows that mobile learning can be an important opportunity for teacher education. Because mobile learning can both contribute to lifelong learning process of teachers and also increase the qualification in undergraduate teacher education. In the second part of the research, a survey is conducted with a sample of prospective teachers in order to provide evidence supporting this situation. In this context, infrastructure and readiness of prospective teachers for mobile learning are examined. Mobile learning infrastructure defines network devices, accessibility and availability of internet to learners and its important for mobile learning (Khan et al., 2015). Mobile tools that prospective teachers have, internet access status, daily average internet usage time and mobile devices usage in lessons for educational purpose are investigated in the context of infrastructure for mobile learning. These features form the basis for the mobile learning of the prospective teachers. The other important dimension for mobile learning is readiness. Readiness; a variable often emphasized and measured in distance education, e-learning, mobile learning and online learning research (Horzum \& Çakır, 2012; Hukle, 2009; Kaymak \& Horzum; 2013). Also readiness is one of the important individual difference variables that affect individuals' acceptance and effectiveness of mobile learning (Hung et al., 2010; Lin et al., 2016). So, it is thought that the prospective teachers' readiness for mobile learning should be examined in current research.

\section{Purpose of Researh}

The purpose of the research is to determine the usability of mobile learning in undergraduate teacher education. In this context, following questions will be answer:

How are mobile learning opportunities that prospective teachers have?

Which are mobile devices prospective teacher have?

How are prospective teachers' internet access opportunities?

How is prospective teachers' daily average internet usage time?

How are prospective teachers' educational usage of mobile devices?

What is the level of prospective teachers' readiness for mobile learning?

Does readiness for mobile learning of prospective teachers differ according to

Gender?

Education level?

Department?

Daily average internet usage time?

\section{Method}

Research Model: Survey model is used for this research. The survey model is a research approach aims to describe a past or existing situation as it exists (Karasar, 2005, Köse, 2013). This study also describes participants' infrastructure and readiness for mobile learning.

Participants: Target population of research consist 454 prospective teachers who study in the 1st and 4th grade of Firat University Faculty of Education during the 2016-2017 academic year. Appropriate sampling method was used in the selection of participants. Demographic characteristics of the participants is given in table 1.

Table 1: Demographic characteristics of prospective teachers 


\begin{tabular}{l|l|l}
\hline & $\mathrm{N}$ & $\%$ \\
\hline Gender Female & 318 & 70 \\
\hline Male & 136 & 30 \\
\hline Education Level 1. & 181 & 39,9 \\
\hline 4. & 273 & 40,1 \\
\hline Department Social Sciences Education & 151 & 33,3 \\
\hline Math and Science Education & 150 & 33,0 \\
\hline Computer and Instructional Technologies & 83 & 18,3 \\
Education & & \\
\hline Basic Education & 70 & 15,4 \\
\hline Total & 454 & 100 \\
\hline Shown in table 1, \%70 of rrospective teach
\end{tabular}

Shown in table 1, $\% 70$ of prospective teachers are female, $\% 30$ of them are male. Departments of participants are ; $\% 33,3$ social sciences education, \%33 math and science education, \%18,3 computer and instructional technologies education, $\% 15,4$ basic education.

Instruments: The data collection tool consists of two parts. Participant demographic form developed by researchers and the readiness scale for mobile learning developed by Lin, Lin, Yeh and Wang (2016) adapted to Turkish by Gökçeaslan, Solmaz and Kukul (2016) is used as data collection tool. Participant demographic form contains information related to demographics of participants. Original form of readiness scale for mobile learning, developed by Lin, Lin, Yeh and Wang (2016), contains 3 factors (self-efficacy, optimism, self directed learning) and totaly 19 items. The scale explains $68.40 \%$ of the total variance. The Croanbach Alfa coefficients was calculated for whole scale; .938, for the self-efficacy subscale .908, for the self directed learning subscale .913, for the optimism subscale .913. Readiness scale for mobile learning was adapted to Turkısh by Gökçeaslan, Solmaz and Kukul (2016). Linguistic equivalence, explatory and confirmatory factor analysis were carried out within the scope of validity and reliability studies. As a result of the validity and reliability studies, 3 factor(self-efficacy, optimism, self directed learning) and totaly 17 items five likert type scale was obtained. The adapted version of scale explains $76.90 \%$ of the total variance. The Croanbach Alfa coefficients was calculated for whole scale .95 , for the self-efficacy subscale .94 , for the self directed learning subscale .89 , for the optimism subscale .95 . Validity and reliability studies related to scale indicate that the scale is valid and reliable. For this research, Croanbach Alfa coefficients was calculated for whole scale .91 , for the self-efficacy subscale .89 , for the self directed learning subscale .80 , for the optimism subscale .81 .

Procedure: The collected data was transferred to the computer after checking and making necessary arrangements. Using parametric statistical tests in analysis of research is a desirable situation in terms of generalizability and reliabilty of results. But some preconditions(normal distribution, equal variance etc) must be met in order to use parametric statistical tests. For this reason, the data were organized by checking descriptive statistics such as standard deviation, mode, median, skewness, kurtosis and $z$ scores to ensure normality of the data obtained in the study. In this procedure performed for the data, $-3,+3$ interval is taken as the criterion for $z$ value. 12 data were extracted from the analysis according to this criteration. After this process normal distribution of the data was observed. Descriptive statistics, including frequency, percentage was used for the analysis related to mobile learning opportunities that prospective teachers have. Mean and standard deviation were used to determine the level of the prospective teachers' readiness for mobile learning. Indepedent sample t test was used to examine the prospective teachers' readiness for mobile learning according to gender and education level variable. One way anova was used to examine the prospective teachers' readiness for mobile learning according to department and daily average internet usage time. Scheffe test was used to determine differences between groups.

\section{Findings}

In this section, there are findings related to infrastructure for mobile learning and the readiness of the prospective teachers for mobile learning.

\section{Findings related to infrastructure for mobile learning of prospective teachers}

Mobile devices that prospective teachers have, the internet access status of prospective teachers and mobile devices usage in lessons were investigated to determine infrastructure for mobile learning of prospective teachers.

Table 2. Infrastructure for mobile learning of prospective teachers 


\begin{tabular}{|c|c|c|c|}
\hline & Mobilephone & 439 & 97 \\
\hline \multirow[t]{3}{*}{ Mobile tools } & Tablet & 71 & 16 \\
\hline & Laptop & 94 & 21 \\
\hline & At least 1 mobile device & 454 & 100 \\
\hline \multirow{6}{*}{ Internet access status } & No internet access & 5 & 1 \\
\hline & Home & 226 & 50 \\
\hline & Out of home & 35 & 8 \\
\hline & School & 81 & 18 \\
\hline & GSM & 316 & 70 \\
\hline & At least 1 internet access opportunity & 449 & 99 \\
\hline \multirow{4}{*}{$\begin{array}{l}\text { Daily average internet usage } \\
\text { time }\end{array}$} & Lower than 1 hour & 79 & 17 \\
\hline & 1-3 hour & 212 & 47 \\
\hline & 4-6 hour & 104 & 23 \\
\hline & 7 hour and over & 59 & 13 \\
\hline \multirow{5}{*}{$\begin{array}{l}\text { Mobile devices usage in lessons } \\
\text { for educational purpose }\end{array}$} & Never & 27 & 6 \\
\hline & Rarely & 93 & 21 \\
\hline & Sometimes & 182 & 40 \\
\hline & Usually & 137 & 30 \\
\hline & Always & 15 & 3 \\
\hline Total & & 454 & 100 \\
\hline
\end{tabular}

Analysis results are shown in table 2, 97\% of the prospective teachers participating in the research have mobile phone, $16 \%$ tablet and $21 \%$ laptop. All of the participants have at least 1 mobile device. $70 \%$ of prospective teacher have internet access on GSM, $50 \%$ at home, $18 \%$ at school and $8 \%$ at out of home. $1 \%$ of teacher prospective have no internet access. $99 \%$ of prospective teachers have at least 1 internet access opportunity. $\% 17$ of the prospective teachers' daily average internet usage time is lower than 1 hour, \%47 1-3 hour, \%23 4-6 hour, \%13 7 hour and over. Prospective teachers are stated that $6 \%$ never, $21 \%$ rarely, $40 \%$ sometimes, $30 \%$ often, $3 \%$ always used mobile devices in lessons for educational purpose.

\section{Findings related to the level of prospective teachers' readiness for mobile learning}

Analysis results related to the level of prospective teachers' readiness for mobile learning is shown in table 3.

Table 3. Level of prospective teachers' readiness for mobile learning

\begin{tabular}{lll}
\hline $\begin{array}{l}\text { Factors (Sub-dimensions) of } \\
\text { readiness for mobile learning }\end{array}$ & Mean & $\begin{array}{l}\text { Standart } \\
\text { Deviation }\end{array}$ \\
\hline Self Efficacy & 3,66 &, 82 \\
Optimism & 3,55 &, 70 \\
Self Directed Learning & 3,61 &, 80 \\
\hline General & 3,60 &, 65 \\
\hline
\end{tabular}

As shown in table 3 , level of prospective teachers' readiness for mobile learning is factor of self efficacy $\bar{X}=3,66$, factor of optimism $\bar{X}=3,55$, factor of self directed learning $\bar{X}=3,61$ and general, $\bar{X}=3,60$.

Findings related to readiness for mobile learning of prospective teachers according to variables.

Prospective teachers' readiness for mobile learning is examined according to gender, department, and average daily internet usage time.

\section{Findings related to readiness for mobile learning of prospective teachers according to gender}

Analysis related to prospective teachers' readiness for mobile learning according to gender is shown in table 4.

Table 4. Readiness for mobile learning of prospective teachers according to gender

\begin{tabular}{lllllll}
\hline Factors & Gender & $\mathrm{N}$ & $\mathrm{X}$ & $\mathrm{Sd}$ & $\mathrm{t}$ & $\mathrm{p}$ \\
\hline Self Efficacy & Female & 318 & 3.67 & .78 & .506 & .614 \\
& Male & 136 & 3.63 & .93 & & \\
\hline
\end{tabular}




\begin{tabular}{lllllll}
\hline Optimism & Female & 318 & 3.54 & .70 & .719 & .466 \\
& Male & 136 & 3.59 & .73 & & \\
\hline Self Directed Learning & Female & 318 & 3.63 & .80 & .720 & .472 \\
& Male & 136 & 3.57 & .83 & & \\
\hline General & Female & 318 & 3.61 & .62 & .126 & .900 \\
& Male & 136 & 3.60 & .72 & & \\
\hline
\end{tabular}

There is no significant difference as a result of independent sample $t$ test between female and male prospective teachers' readiness for mobile learning.

Findings related to readiness for mobile learning of prospective teachers according to education level

Analysis related to prospective teachers' readiness for mobile learning according to education level is shown in table 5 .

Table 5. Readiness for mobile learning of prospective teachers according to education level

\begin{tabular}{lllllll}
\hline Factors & Grade & $\mathrm{N}$ & $\mathrm{X}$ & $\mathrm{Sd}$ & $\mathrm{t}$ & $\mathrm{p}$ \\
\hline Self Efficacy & 1 & 181 & 3.65 & .78 & .092 & .927 \\
& 4 & 273 & 3.66 & .86 & & \\
\hline Optimism & 1 & 181 & 3.57 & .71 & .408 & .684 \\
& 4 & 273 & 3.54 & .71 & & \\
\hline Self Directed Learning & 1 & 181 & 3.58 & .78 & .805 & .422 \\
& 4 & 273 & 3.64 & .83 & & \\
\hline General & 1 & 181 & 3.60 & .62 & .092 & .927 \\
& 4 & 273 & 3.61 & .67 & & \\
\hline
\end{tabular}

There is no significant difference as a result of independent sample $t$ test between 1. and 4. education level prospective teachers' readiness for mobile learning.

Findings related to readiness for mobile learning of prospective teachers according to department

Analysis related to prospective teachers' readiness for mobile learning according to department is shown in table 6 .

Table 6. Readiness for mobile learning of prospective teachers according to department.

\begin{tabular}{llllllll}
\hline Factors & & $\begin{array}{l}\text { Sum of } \\
\text { square }\end{array}$ & df & $\begin{array}{l}\text { Mean } \\
\text { square }\end{array}$ & $F$ & $p$ & Mean .differance \\
\hline \multirow{2}{*}{ Self Efficacy } & Betwen groups & 9,285 & 3 & 1,050 & 1,551 &, 201 & - \\
& Within groups & 236,222 & 450 &, 677 & & & \\
& Total & 245,507 & 453 & & & & \\
\hline \multirow{2}{*}{ Optimism } & Betwen groups & 7,688 & 3 &, 423 &, 841 &, 472 & - \\
& Within groups & 217,622 & 450 &, 503 & & & \\
& Total & 225,310 & 453 & & & & \\
\hline Self Directed & Betwen groups & 4,184 & 3 &, 389 &, 594 &, 619 & - \\
Learning & Within groups & 225,029 & 450 &, 654 & & & \\
& Total & 229,213 & 453 & & & & \\
\hline General & Betwen groups & 4,065 & 3 &, 432 & 1,023 &, 382 & - \\
& Within groups & 210,204 & 450 &, 422 & & & \\
\hline
\end{tabular}




Total 214,269 453

There is no significant difference as a result one way anova test between departments of prospective teachers.

Findings related to readiness for mobile learning of prospective teachers according daily average internet usage time.

Analysis related to prospective teachers' readiness for mobile learning according to daily average internet usage time is shown in table 7.

Table 7. Readiness for mobile learning of prospective teachers according to daily average internet usage time

\begin{tabular}{llllllll}
\hline Factors & & $\begin{array}{l}\text { Sum of } \\
\text { square }\end{array}$ & df & $\begin{array}{l}\text { Mean } \\
\text { square }\end{array}$ & F & $p$ & $\begin{array}{l}\text { Sign. Diff. } \\
\text { Scheffe }\end{array}$ \\
\hline \multirow{2}{*}{ Self Efficacy } & Betwen groups & 10,465 & 3 & 3,488 & 5,280 &, 001 & $\begin{array}{l}\text { 7 hours and over- } \\
\text { lower than 1 hour }\end{array}$ \\
& Within groups & 297,272 & 450 &, 661 & & & \\
& Total & 307,736 & 453 & & & & \\
\hline \multirow{2}{*}{ Optimism } & Betwen groups & 2,004 & 3 &, 668 & 1,333 &, 263 & - \\
& Within groups & 225,437 & 450 &, 501 & & & \\
& Total & 227,441 & 453 & & & & \\
\hline Self Directed & Betwen groups & 2,232 & 3 &, 744 & 1,142 &, 332 & - \\
Learning & Within groups & 293,301 & 450 &, 652 & & & \\
& Total & 295,533 & 453 & & & & \\
\hline General & Betwen groups & 2,894 & 3 &, 965 & 2,304 &, 076 & - \\
& Within groups & 188,391 & 450 &, 419 & & & \\
& Total & 191,284 & 453 & & & & \\
\hline
\end{tabular}

There is significant difference on factors of self efficacy as a result one way anova test. The scheffe test is conducted to determine which groups differed. According to results of scheffe test, self efficacy level of prospective teachers who use internet daily 7 hours and over $(\bar{X}=3,96)$ is higher than prospective teachers who use internet daily lower than 1 hour ( $\bar{X}=3,40)$.

\section{Results, Discussions and Conclusions}

Review and survey were carried out within the scope of this research. Review for this research shows that mobile learning can be an opportunity for teacher education. Because it is necessary for the teaching profession to learn lifelong like other professions (European Commission, 2005). Also mobile learning offers learning opportunities in every where and every time (Geddes, 2004; Traxler, 2007). One of the important results of this research is that almost all of prospective teacher have the mobile tools necessary for mobile learning and they have opportunities to access internet. Daily average internet usage time of prospective teachers is higher. It was determined that a significant number of prospective teachers use more than one hour of internet on average per day. It has been determined that prospective teachers frequently use mobile tools and use mobile tools partially for educational purposes. It is an important finding that nearly all of the prospective teachers have a smartphone and most of them have internet access opportunities. Because mobile phones now have same capabilities as microcomputers at a small fraction of the size and currently the most widely used devices for mobile learning (Crompton, 2013; Hsiao and Chen, 2014; Hussin et al., 2012; Wu et al., 2012). Results indicates that the prospective teachers have the necessary infrastructure for mobile learning. Also they use mobile devices for educational purposes in their lessons. These are advantageous faciliators for using mobile learning in undergraduate teacher education.

It has been determined that the level of prospective teachers' readiness for mobile learning has partially high $(x=3.60)$ and the level of prospective teachers' readiness for mobile learning is not differ according to gender, educational level and department variables. But prospective teachers' readiness for mobile learning differs according to the average daily internet use. The result of level of prospective teachers' readiness for mobile learning has partially high shows that prospective 
teachers can easily benefit from mobile learning. Because readiness is an important variable for effectiveness of mobile learning(Hung et al., 2010; Lin et al., 2016) and some other learning aproaches such as distance education, online learning etc. (Horzum \& Çakır, 2012; Hukle, 2009; Kaymak \& Horzum; 2013). So, it can be concluded that prospective teachers are partially ready for mobile learning. It can be said that prospective teacher show homogeneous characteristics related to mobile learning. Because prospective teachers' readiness for mobile learning is not differ according to their some characteristics(gender, education level, department). But it can be expected that those who use internet more intensively have higher self-efficacy in mobile learning than who use internet lower. Considering that future generations migth use the internet more intensely, it may be thought that their readiness for learn mobile learning might be higher. It is an interesting result that there is no difference between groups according to education level. This result may suggest that undergraduate education does not affect prospective teachers' readiness for mobile learning. But this is not an experimental study, so it may not be right to interpret this conclusion. The level of education can be interpreted as a variable age variable. Because it is estimated that the age of participants is between 18-22 years when the age of starting the undergraduate education in Turkey is 18 (Günay\&Günay, 2016). It can be assumed that being no difference between the groups in this research is due to the fact that the participants are digital natives. Because they have mobile devices and internet access also use internet frequently and they have higher readiness for mobile learning. Also higher readiness of prospective teachers for mobile learning can also be due to their digital native characteristics. Because in recent research, conducted by Teo et al.(2016), Turkish prospective teachers have defined themselves as digital natives.

The results of the research show that mobile learning is an approach that should be taken into account for undergraduate teacher education as well as teacher education. Because mobile learning benefical, increasing trend and have pedagogical affordances for teacher education (Baran, 2014; Ferry, 2009). Also effective professional learning requires reflection and collaboration and that mobile learning is ideally suited to allow reflection-inaction and to capture the spontaneity of learning moments(Abusson, Schuck \& Burden, 2009; Walsh, Shrestha \& Hedges, 2013). Current research shows that prospective teachers have a great potential for mobile learning. Because prospective teachers have the necessary infrastructure and readiness for mobile learning. Mobile learning is an approach that can be provide significant contributions to both undergraduate teacher education and professional development. Therefore it would be useful to use mobile learning both undergraduate teacher education and in-service training.

It can be seen as a limitation that this research only examines the infrastructures and readiness of prospective teachers for mobile learning. Because these variables can not explain mobile learning in teacher education. Other variable such as mobile learning adoption, attitude and motivation of prospective teachers should be examined. These studies should be conducted different and large samples. Besides experimental and mixed method studies should be conducted. It is thought that the results of these studies will form the theoretical basis for mobile learning in teacher education.

\section{References}

[1] Al-Fahad, F. N. (2009). Students' attitudes and perceptions towards the effectiveness of mobile learning in King Saud University, Saudi Arabia. Turkish Online Journal of Educational Technology, 8(2), 111-119.

[2] Attewell, J. (2005). From research and development to mobile learning: Tools for education and training providers and their learners. 4th World Conference on mLearning (pp. 1-6).

[3] Aubusson, P., Schuck, S., \& Burden, K. (2009). Mobile learning for teacher professional learning: benefits, obstacles and issues. ALT-J, 17(3), 233-247.

[4] Behera, K. S. (2013). M-learning: A new learning paradigm. International Journal on New Trends in Education and Their Implications, 4(2), 24-34.

[5] Chen, X. B. (2013). Tablets for informal language learning: Student usage and attitudes. Language Learning \& Technology, 17(1), 20-36.

[6] Cheon, J., Lee, S., Crooks, S. M. \& Song, J. (2012). An Investigation of mobile learning readiness in higher education based on the theory of planned behavior. Computers \& Education, 59(3), 1054-1064.

[7] Cheong, J.H. \& Park, M.-C. (2005). "Mobile internet acceptance in Korea", Internet Research, 15 (2), 125140.

[8] Christensen, R., \& Knezek, G. (2017). Validating a Mobile Learning Readiness Survey: Assessing Teachers' Dispositions Toward Adoption. Journal of Digital Learning in Teacher Education, 1-12.

[9] Chu, H.C. (2014), "Potential negative effects of mobile learning on students' learning achievement and cognitive load - a format assessment perspective", Educational Technology \& Society, 17(1), 332-344. 
[10] Ciampa, K. (2014). Learning in a mobile age: An investigation of student motivation. Journal of Computer Assisted Learning, 30(1), 82-96.

[11] Crompton, H. (2013). A historical overview of mobile learning: toward learner-centered education. In Z. Berge and L. Muilenburg (Eds.), Handbook of Mobile Learning (pp 3-4), NewYork, NY: Routledge.

[12] Çelik, A. (2013). M-Öğrenme tutum ölçeği: Geçerlik ve güvenirlik analizleri. Journal of Research in Education and Teaching, 2(4), 172-185.

[13] Europeia, C. (2005). Common European principles for teacher competences and qualifications. Bruxelas: European Commission, Directorate-General for Education and Culture. Retrieved 25 Agust 2017.

[14] Ferry, B.(2009). Using mobile phones to enhance teacher learning in environmental education, in Herrington, J, Herrington, A, Mantei, J, Olney, I and Ferry, B (editors), New technologies, new pedagogies: Mobile learning in higher education, Faculty of Education, University of Wollongong, 45-55.

[15] Franklin, T. (2011). Mobile learning: at the tipping point. Turkish Online Journal of Educational TechnologyTOJET, 10(4), 261-275.

[16] Geddes, S. J. (2004). Mobile learning in the 21st century: benefit for learners. Knowledge Tree ejournal, 30(3), 214-228.

[17] Gökçearslan, Ş., Solmaz, E., \& Kukul, V. (2017). Mobil öğrenmeye yönelik hazırbulunuşluk ölçeği: Bir uyarlama çalışması. Eğitim Teknolojisi Kuram ve Uygulama, 7(1), 143-157.

[18] Güleç, I., Çelik, S. \& Demirhan, B.(2012) "Yaşam boyu öğrenme nedir? Kavram ve kapsamı üzerine bir değerlendirme." Sakarya University Journal of Education 2(3), 34-48.

[19] Günay, D., \& Günay, A. (2016). Dünyada ve Türkiye'de Yükseköğretim Okullaşma Oranları ve Gelişmeler. Journal of Higher Education \& Science/Yüksekögretim ve Bilim Dergisi, 6(1), 13-30.

[20] Horzum, M. B., \& Cakir, O. (2012). Structural equation modeling in readiness, willingness and anxiety of secondary school students about the distance learning. Procedia-Social and Behavioral Sciences, 47, 369375.

[21] Horzum, M. B., \& Kaymak, Z. D. (2013). Çevrimiçi öğrenme öğrencilerinin çevrimiçi öğrenmeye hazır bulunuşluk düzeyleri, algıladıkları yapı ve etkileşim arasındaki ilişki. KUYEB, 13(3), 1783-1797.

[22] Hsiao, M.-H., \& Chen, L.-C., 2014. Smart phone demand: an empirical study on the relationships between phone handset, Internet access and mobile services. Telematics Inform. 32 (1), 158-168

[23] Hukle, D. R. L. (2009). An evaluation of readiness ractors for online education. Unpublished doctoral dissertation, Mississippi State University, Mississippi.

[24] Hussin, S., Manap, M. R., Amir, Z., \& Krish, P. (2012). Mobile learning readiness among Malaysian students at higher learning institutes. Asian Social Science, 8(12), 276.

[25] Hwang, G. J., \& Chang, H. F. (2011). A formative assessment-based mobile learning approach to improving the learning attitudes and achievements of students. Computers \& Education, 56(4), 1023-1031.

[26] Işık, A. H., Özkaraca, O., \& Güler, İ. (2011). Mobil öğrenme ve podcast. XII. Akademik Bilişim Konferansı Bildirileri.

[27] Jacob, S. M., \& Issac, B. (2014). The mobile devices and its mobile learning usage analysis. arXiv preprint arXiv: 1410.4375

[28] Jaradat, R. M. (2014). Students' attitudes and perceptions towards using m-learning for French language learning: A case study on Princess Nora University. International Journal of Learning Management Systems, 2(1), 33-44.

[29] Karasar, N. (2005). Bilimsel Araştırma Yöntemi. Ankara: Nobel Yayın-Dağııım.

[30] Kearney, M., \& Maher, D. (2013). Mobile learning in math teacher education: Using iPads to support preservice teachers' professional development. Australian Educational Computing, 27(3), 76-84.

[31] Khan, A. I., Al-Shihi, H., Al-Khanjari, Z. A., \& Sarrab, M. (2015). Mobile Learning (M-Learning) adoption in the Middle East: Lessons learned from the educationally advanced countries. Telematics and Informatics, 32(4), 909-920.

[32] Köse, E. (2013). Bilimsel araştırma modelleri. Remzi Y. Kıncal (Ed). Bilimsel araştırma yöntemleri. Nobel Yayın Dağıtım.

[33] Kutluk, F. A. \& Gulmez, M. (2014). A research about mobile learning perspectives of university students who have accounting lessons. Procedia-Social and Behavioral Sciences, 116, 291-297. 
[34] Lin, H. H., Lin, S., Yeh, C. H., \& Wang, Y. S. (2016). Measuring mobile learning readiness: scale development and validation. Internet Research, 26(1), 265-287.

[35] Martin, F. \& Ertzberger, J. (2013). Here and now mobile learning: An experimental study on the use of mobile technology. Computers \& Education, 68, 76-85.

[36] Newhouse, C. P., Williams, P. J., \& Pearson, J. (2006). Supporting mobile education for pre-service teachers. Australasian Journal of Educational Technology, 22(3), 289-311.

[37] O'Malley, C., Vavoula, G., Glew, J., Taylor, J., Sharples, M. \& Lefrere, P. (2003) Guidelines for learning/teaching/tutoring in a mobile environment. Mobilearn Project deliverable. http://www.mobilearn.org/download/results/guidelines.pdf

[38] Ozan, O. (2013) Bağlantıcı mobil öğrenme ortamlarında yönlendirici destek. Yayımlanmamış doktora tezi, Anadolu Universitesi, Sosyal Bilimler Enstitusu, Eskişehir.

[39] Oz, H. (2014). Prospective English teachers' ownership and usage of mobile devices as m-learning tools. Procedia-Social and Behavioral Sciences, 141, 1031-1041.

[40] Pachler, N., Cook, J., Bachmair, B. \& Kress, G. (Ed.). (2010). Mobile learning: Structures, agency, practices. London: Springer.

[41] Quinn, C. (2000) mLearning: Mobile, Wireless and In-Your-Pocket Learning. Line Zine Magazine. http://www.linezine.com/2.1/features/cqmmwiyp.htm

[42] Sha, L., Looi, C.-K., Chen, W., Seow, P. \& Wong, L.-H. (2012), "Recognizing and measuring self-regulated learning in a mobile learning environment", Computers in Human Behavior, 28 (2), 718-728.

[43] Shepherd, C. (2001) M is for Maybe. Tactix: Training and communication technology in context. http://www.fastrak-consulting.co.uk/tactix/features/mlearning.htm

[44] Shih, J.-L., Chuang, C.-W. and Hwang, G.-J. (2010), "An inquiry-based mobile learning approach to enhancing social science learning effectiveness", Educational Technology \& Society, 13 (4), 50-62.

[45] Shudong, W., \& Higgins, M. (2005, November). Limitations of mobile phone learning. In Wireless and Mobile Technologies in Education, 2005. WMTE 2005. IEEE International Workshop on (pp. 3-pp). IEEE.

[46] Sur, E. (2011). Mobil öğrenme ve web destekli öğrenme yöntemlerinin karşılaştırılması (Sinop Üniversitesi Gerze Meslek Yüksekokulu'nda bir uygulama). Yayımlanmamış yüksek lisans tezi, Gazi Universitesi, Bilişim Enstitusu, Ankara.

[47] Teo, T., Kabakçı Yurdakul, I., \& Ursavaş, Ö. F. (2016). Exploring the digital natives among pre-service teachers in Turkey: a cross-cultural validation of the Digital Native Assessment Scale. Interactive Learning Environments, 24(6), 1231-1244.

[48] Traxler, J. (2005, June). Defining mobile learning. In IADIS International Conference Mobile Learning (pp. 261-266).

[49] Traxler, J., (2007). Defining, Discussing and Evaluating Mobile Learning: The moving finger writes and having writ. . . The International Review of Research in Open and Distance Learning 8(2).

[50] Walker, K. (2006). Introduction: Mapping the landscape of mobile learning. In Big Issues in Mobile Learning. Report of a workshop by the Kaleidoscope Network of Excellence Mobile Learning Initiative. Learning Sciences Research Institute. University of Nottingham.

[51] Walsh, C. S., Shrestha, P., \& Hedges, C. (2013). Mobile phones for professional development and English teaching in Bangladesh. International Journal of Innovation and Learning, 13(2), 183-200.

[52] Wang, M., Shen, R., Novak, D., \& Pan, X. (2009). The impact of mobile learning on students' learning behaviours and performance: Report from a large blended classroom. British Journal of Educational Technology, 40(4), 673-695.

[53] Wang, W.-T. \& Li, H.-M. (2012), "Factors influencing mobile services adoption: a brand-equity perspective", Internet Research, 22 (2), 142-179.

[54] Wu, W. H., Wu, Y. C. J., Chen, C. Y., Kao, H. Y., Lin, C. H., \& Huang, S. H. (2012). Review of trends from mobile learning studies: A meta-analysis. Computers \& Education, 59(2), 817-827.

[55] Yılmaz Y. (2011). Mobil Öğrenmeye yönelik lisansüstü öğrencilerinin ve öğretim elemanlarının farkındalık düzeylerinin araştırıması. Dokuz Eylül Üniversitesi Eğitim Bilimleri Enstitüsü. Yayınlanmış Yüksek Lisans Tezi. 